\title{
Some Reflections on Juvenile Policy of The Republic Of Uzbekistan
}

\author{
Vokhidjon Topildiev, National University of Uzbekistan \\ Faxriddin Yarmanov, Karshi Stat University Republic of Uzbekistan fyarmanov@bk.ru
}

\begin{abstract}
This article discusses the theoretical and practical issues of Uzbekistan's youth policy, the legal basis of education and the protection of the rights of the child, as well as questions concerning the powers of the subjects. State policy of the Republic of Uzbekistan on juvenile delinquency as well as the current state of Uzbekistan is that a number of ministries and departments (justice, education, home affairs, labor relations and employment, prosecutors, etc.) deal with the problems of minor children. It is realized that yet there is no clear coordination or interaction between these departments, which would define clear goals and objectives. This leads to the fact that each department solves individual problems. The lack of alternative programs makes it difficult to effectively implement reforms in the area of juvenile justice.
\end{abstract}

Keywords: State, youth policy, legal support of youth policy, protection of children's rights, declaration, convention, implementation of state policy, social support.

$\begin{array}{lll}\text { Received: 07.12.2020 } & \text { Accepted: 18.01.2021 } & \text { Published: 02.02.2021 }\end{array}$

\section{Introduction.}

During the years of independence, an effective mechanism for the protection of the rights of the child has been put in place and is continuously improved in Uzbekistan. The national system for the protection of children's rights and freedoms established in Uzbekistan includes legislation governing relations in the field of guaranteeing human rights and the system of state and public institutions guaranteeing the achievement of all the rights and freedoms set forth in the Constitution and in the legislation of the Republic, adopted taking into account the norms of international law generally.

Today, in Uzbekistan, a number of ministries and departments (justice, education, home affairs, labor relations and employment, prosecutors, etc.) deal with the problems of minor children. But there is no clear coordination and interaction between these departments, which would define clear goals and objectives. This leads to the fact that each department solves individual problems. The lack of alternative programs makes it difficult to effectively implement reforms in the area of juvenile justice.

\section{Materials and methods.}

The birth of a child, its social and moral development, and the introduction to socially useful activities have always been the immediate concerns of the family, society and the State, and the well-being of the family, the child public and state largely depend on the effective solution of these tasks.

The development of children in love and safety, their guaranteed education and the necessary legal protection bear witness to the moral health of society and the social and legal orientation of state policy.

Social pragmatism is inherent in the care of the young generation: society and the state have the right to expect parents who take care of these children, defend the homeland in times of need, work conscientiously, adopt a behavior law-abiding and socially recognized inherent in educated and educated individuals, which determines social stability and strong government are the foundations of any society and political system. As seventeenth-century English educator John Locke said, "The well-being of everyone depends on the proper education of children," argues the eighteenth-century French philosopher Claude Adrian Helvetius in his concepts: "The more education is perfect, the more people are perfect".

The protection of children and their education is the most important function of state activity, which is based on effective legal regulation of this area of public relations.

Youth policy is an integral part of state social policy aimed at creating conditions for a decent life and free development of the person. The state guarantees support for the family, motherhood and childhood (article 63 of the Constitution of the Republic of Uzbekistan).

\section{Discussion.}


Politics (from the Greek. Politics - the art of governing the state) in relation to the term "minor" (from lat. Guvenis, gunior - junior, young, young) means public administration in the social field aimed at guarantee the interests of society for the protection of children's rights.

The main and most effective means of youth policy are legal ones.

Legal support for the policy on minors is based on:

- The universally recognized principles and norms of international law, which form part of the legal system of the Republic of Uzbekistan when concluding relevant international treaties;

- The Constitution of the Republic of Uzbekistan;

- Laws and other regulatory legislative acts of the Republic of Uzbekistan;

- The laws and other regulatory acts of the Republic of Karakalpakstan on the protection of the rights and legitimate interests of the child.

The most important international legal acts in the field of youth policy are:

- Geneva Declaration on the Rights of the Child, adopted by the League of Nations in 1924;

- Universal Declaration of Human Rights, adopted by the United Nations in 1948, which stipulates that children should be the subject of special protection and assistance;

The Declaration of the Rights of the Child, adopted by the United Nations in 1959 and proclaiming ten social and legal principles relating to the protection and well-being of children;

- United Nations Convention on the Rights of the Child of 1989, which considerably developed and detailed the fundamental rights of the child, determining the direction and content of the youth policy of the States Parties to the Convention;

- World Declaration on the Survival, Protection and Development of Children of 1990;

The United Nations Minimum Rules for the Administration of Juvenile Justice (Beijing Rules), 1985;

- United Nations Guidelines for the Prevention of Juvenile Delinquency (Riyadh Guidelines), 1990 and others.

United Nations Minimum Rules for the Administration of Juvenile Justice (Beijing Rules) 1985;

- United Nations Guidelines for the Prevention of Juvenile Delinquency (Riyadh Guidelines), 1990 and others.

In the legislation of the Republic of Uzbekistan, which determines the state policy in matters of minors, it is worth highlighting the law on guarantees of the "Rights of the Child '", which established legal mechanisms for the protection of the rights and legitimate interests of the child and defined the principles of this policy:

1) legislative support for the rights of the child;

2) support of the family to ensure the education, leisure and health of children, the protection of their rights, the preparation for a full life in society;

3 ) liability of officials and citizens for violation of the rights and legitimate interests of the child who caused him harm;

4) the support of public associations and other organizations carrying out activities aimed at protecting the rights and legitimate interests of the child.

In this law, the objectives of the political state of the Republic of Uzbekistan in the interests of children, which is fully in line with the concept of "youth policy", namely:

- Protection of the rights of the child stipulated by the Constitution of the Republic of Uzbekistan;

- Determination of priority orientations to guarantee the rights of the child;

- Execution of legislation on guarantees of children's rights;

- Development and implementation of state and territorial programs aimed at guaranteeing the rights, freedoms and legitimate interests of the child;

- Coordination and control of the activities of state bodies, child protection institutions and children's rights organizations

- To finance, in accordance with the established procedure, the necessary measures for the implementation of the policy of protection of the rights of the child at the expense of the budget of the Republic of Uzbekistan and other sources not prohibited by law;

- Adoption of measures aimed at strengthening the material and technical base of public children's institutions and promoting the development of non-state children's institutions;

- Monitor the observance of the international obligations of the Republic of Uzbekistan and represent the interests of the Republic of Uzbekistan in international organizations responsible for ensuring respect for the rights of the child;

- Information and education activities;

- Solve support problems for socially vulnerable children.

State authorities and administrations may exercise other powers in accordance with the law.

1) establish the foundation for federal policy in the best interests of children; 
2) the selection of priority activities to guarantee the rights and legitimate interests of the child, the protection of his health and morals;

3) the formation and implementation of targeted federal programs for the protection of the rights of the child and the assistance to children and the determination of the responsibility for the execution of such programs by bodies, institutions and organizations

4) establish the procedure for judicial protection and judicial protection of the rights and legitimate interests of the child;

5) fulfillment of the international obligations of the Republic of Uzbekistan and representation of the interests of the Republic of Uzbekistan in international organizations for the protection of children's rights.

- solve the problems of social support and social services for orphans and children left without parental care, neglected children, disabled children;

- assist the child in the implementation and protection of his rights, freedoms and legitimate interests, provide legal, methodological, informational or other assistance to the child or his legal representative.

The Law of the Republic of Uzbekistan "On Prevention of Neglect and Juvenile Delinquency" defines the following main tasks and principles for the prevention of neglect and delinquency

- prevention of neglect, homelessness of minors, the commission of offenses or other anti-social acts, identification and elimination of the causes and conditions which lead to them;

- ensure the protection of the rights, freedoms and legal interests of minors;

- training in law-abiding behavior for minors;

- social and educational rehabilitation of minors and families in a socially dangerous situation;

- identification and removal of cases involving minors in the commission of offenses or other antisocial acts.

And also determined the list of subjects included in the system of this activity:

commissions for the affairs of minors and the protection of their rights;

- authorities for social protection of the population;

- educational authorities;

- supervisory and supervisory authorities;

- youth bodies;

- health authorities;

- employment service agencies;

- Internal affairs bodies.

These subjects should not be confused with those of public policies relating to minors, as they concern a particular area of the implementation of juvenile policy, namely the prevention of neglect and juvenile delinquency.

Youth policy is closely linked to youth policy, which aims to create legal, economic and organizational conditions and to ensure the realization of a young person's personality.

people aged 14 to 30 (Law of the Republic of Uzbekistan "On State Youth Policy" of September 14, 2016)

The strategy of actions for the five priority axes of development of the Republic of Uzbekistan for 20172021 includes:

- a physically healthy, spiritually and intellectually developed education, with an independent spirit, dedicated to the young people of the motherland who have a deep vision of life, strengthening its social activity in the process of deepening democratic reforms and civil society;

- employment and attractiveness in the sphere of private entrepreneurship of graduates of special secondary, vocational and higher education establishments;

- support and realization of the creative and intellectual potential of the young generation, formation of a healthy lifestyle in children and young people, widespread participation in physical culture and sports, social protection for young people, creation of decent housing and social conditions for young families, its extensive public relations on the legal protection of the child himself, the family, the organization of the process of safe development of children, the prevention of the commission of offenses, etc.

\section{Conclusion.}

In our opinion, to solve this problem, it is necessary to solve the problems of economic development, employment and decent wages, medical care and social security, etc. For in youth policy the emphasis is on the participation of young people in the social, economic, political and cultural life of society, their inclusion in socially useful activities.

The policy of minors only has meaning and an objective component if it is organically included in the policy of the welfare state.

\section{REFERENCES:}


1. Aforızmy. - Mn.: Harvest, - M.: AST, 2000. p. 106, 107.

2. Zakon Respublıkı Uzbekıstan «0 garantıah prav rebenka » «Sobranı zakonodatelstva Respublıkı Uzbekıstan », 2008 g., N 1-2, p. 1.

3. Zakon Respublıkı Uzbekıstan «O profılaktıkı beznadzornostı 1 pravonarushenı sredı nesovershennoletnıh» « Sobranıe zakonodatelstva Respublıkı Uzbekıstan », 2010 g., № 39, p. 341.

4. Zakon Respublıkı Uzbekıstan «0 gosudarstvennoı molodejnoı polıtıkı» "Sobranıe zakonodatelstva Respublıkı Uzbekıstan », 19 sentıabrıa 2016 g., № 37, p. 426.

5. Ukaz Prezıdenta Respublıkı Uzbekıstan «O strategıı deıstvı po dalneıshemu razvıtılu Respublıkı Uzbekıstan » 07.02.2017 goda. « Sobranıe zakonodatelstva Respublıkı Uzbekıstan », 13 fevralıa 2017 g., № 6, p. 70.

Fayziyev Shokhrud Farmonovich Medical law and features of legal relations arising in the provision of medical services. International journal of pharmaceutical research Volume 11, Issue 3, July - Sept, 2019 P. 1197-1200

http://www.ijpronline.com/ViewArticleDetail.aspx?ID=11016

doi:10.31838/ijpr/2019.11.03.088

Bryanskaya Elena, Fayziev Shokhrud, Altunina Anna, Matiukha Alena Topical Issues of an Expert Report in the Process of Proving in a Criminal Examination. International Journal of Engineering and Advanced Technology (IJEAT) ISSN: 2249 - 8958, Volume-9 Issue-1, October 2019 5345-5349 DOI: $10.35940 /$ ijeat.A2946.109119

content/uploads/papers/v9i1/A2946109119.pdf

https://www.ijeat.org/wp-

Fayziev Shokhrud (2019) Legal Aspects of Transplantology in the Republic of Uzbekistan. Systematic Reviews in Pharmacy, ISSN: 0976-2779, Vol: 10, Issue: 2, Page: 44-47 doi:10.5530/srp.2019.2.08 http://www.sysrevpharm.org//fulltext/196-1575419211.pdf?1586863081

Tulaganova, G. Some issues of observance of international legal norms of fight against legalization of criminal incomes in the Republic of Uzbekistan Journal of Advanced Research in Dynamical and Control Systems 12(2 Special Issue), P. 143-155

Bazarova D. Some problems of counteracting crimes related to laundering of illegal proceeds in Uzbekistan Journal of Advanced Research in Dynamical and Control Systems. Volume 11, Issue 7, 2019, Pages 873-885 